В.В. Шмаков, В.В. Бараннік, А.О. Красноруцький, О.В. Федоровський, О.О. Олексін

Харківський національний університет Повітряних Сил ім. І. Кожедуба, Харків

\title{
МЕТОДИКА ПЕРЕВІРКИ ТА ВІЙСЬКОВОГО РЕМОНТУ БЛОКУ ГЕТЕРОДИНІВ СТАНЦІЇ РЕБ СПС-99 ВЕРТОЛЬОТУ МИ-8МТПИ ("ИКЕБАНА")
}

\begin{abstract}
Розкрита методологія радіотехнічної розвідки та постановки завад з наземного положення та з зони баражування вертольоту. Пропонується метод військового ремонту блоку гетеродинів станиії СПС-99, щуо забезпечує зменшення працевтрат на усунення несправності та збільшення коефіцієнту безвідмовної роботи станиії в ичілому. Надано модель виміру поточних параметрів та корегування їх номінальних значень блоку гетеродинів Л161-23. Запропонована модель роботи функціональної схеми автогенератора 3 фазовим автоматичним налаштуванням частоти станщіï СПС-99.
\end{abstract}

Ключові слова: радіоелектронна боротьба, радіорозвідка, гетеродин, автогенератор, частота.

\section{Вступ}

Розвиток інформаційних технологій дозволяє інтегрувати в систему радіоелектронної боротьби спеціальних радіоелектронних бортових засобів, які мають можливість надання інформаційної складової радіоелектронної розвідки з метою виконання завдання постановки завади в заданому напрямку, а також з визначеною послідовністю.

Вирішення питань ефективності функціонування існуючих бортових станцій радіоелектронної боротьби при управлінні в умовах кризової ситуації, пов'язане 3 існуванням суттєвої проблеми забезпечення справності складових частин спеціального бортового радіоелектронного обладнання вертольота. Це є суттю науково-прикладної проблеми, яка розглядається в статті. Причина тут полягає в існуючому дисбалансі між достовірністю отриманих даних радіорозвідки і оперативністю постановки потрібної завади [1-5].

Це пов'язане з особливістю технології обробки сигналів в існуючій авіаційній спеціальній радіотехнічній апаратурі, що входить до системи радіорозвідки. Пояснюється це тим, що з прийнятого сигналу потрібно синтезувати інформацію яка стосується несучої частини, довжини імпульсів, що приймаються, а також їх частоту повторення.

В подальшому ці дані будуть використані при формуванні загороджувальних шумових завад або лінійно-частотної модуляції (ЛЧМ) під час формування глибини прикриття: попереду та за собою.

Аналіз останніх досліджень і публікацій. В сучасних умовах ведення бойових дій значно зросло значення радіоелектронної боротьби (РЕБ), як одного з важливих видів оперативного і бойового забезпечення. Засоби РЕБ використовуються не стільки в оборонному значенні, як для наступальних активних дій. Вміле застосування засобів РЕБ гарантує успіх дій ударної авіації та вантажних перевезень під час бойових дій [6-7]. Складовою тут $є$ існуючий парк вертольотів, на яких встановлене спеціальне обладнання радіоелектронної боротьби.

Їх завдання - створити безпечні умови для застосування авіації в умовах ведення противником протиповітряної оборони. Баражуючи неподалік лінії зіткнення, постановники перешкод здатні з легкістю подавити засоби виявлення та наведення авіаційних і наземних засобів ураження ворога на глибині понад сто кілометрів. При цьому встановлене на вертольоти обладнання РЕБ однаково ефективно глушить бортові прицільні комплекси літаків й наземні засоби радіотехнічних військ (РТВ) та зенітно-ракетних військ (ЗРВ) [8-9].

Для прийняття тактично-грамотного рішення щодо застосування існуючих вертольотів РЕБ при забезпеченні подолання зони протидії зенітноракетних комплексів (ЗРК) авіаційною складовою, необхідно визначити ряд параметрів щодо загальних даних розгорнутих та діючих засобів протиповітряної оборони як противника так і своїх військ, ті що знаходяться поблизу лінії зіткнення.

В Україні активно відновлюють авіаційну систему радіоелектронної боротьби, завдяки інтенсивним роботам з відновлення авіаційних засобів РЕБ групового захисту, які базуються на вертольотах Ми-8МТПБ (“Бизон”) та Ми-8МТПИ (“Икебана”) Загальний вид вертольотів РЕБ наданий на рис. 1 та рис. 2.

Засоби РЕБ таких вертольотів призначені для виявлення та зниження ефективності дії радіоелектронних систем (РЕС) противника, які працюють в діапазоні сантиметрових та дециметрових хвиль, 3 метою ускладнення обробки інформації від РЕС. I $€$ можливість прикриття бойових порядків авіації від виявлення з боку РЛС противника, зриву прицільної стрільби по наших літаках. 


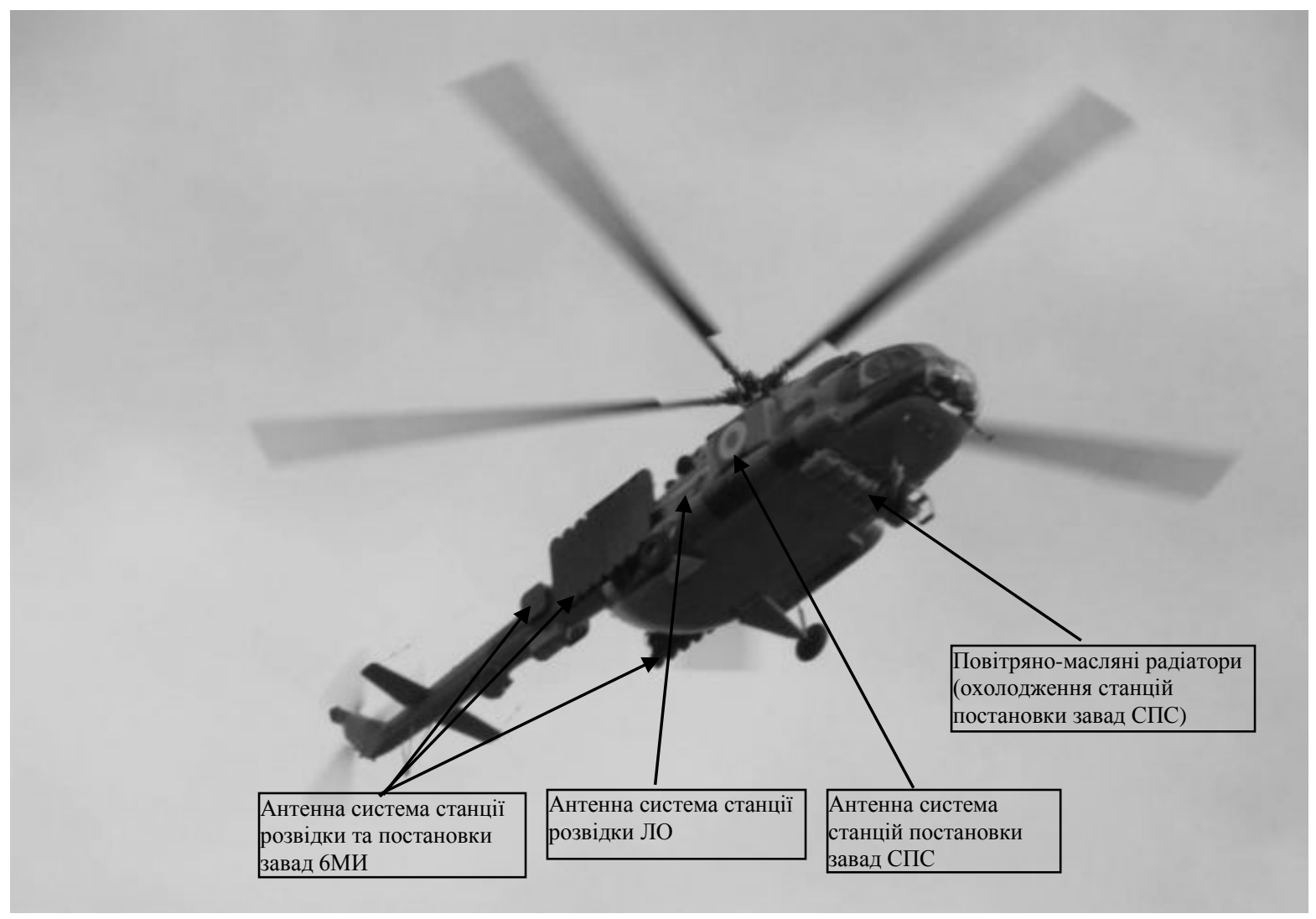

Рис. 1. Вертоліт Ми-8МТПБ (“Бизон”)

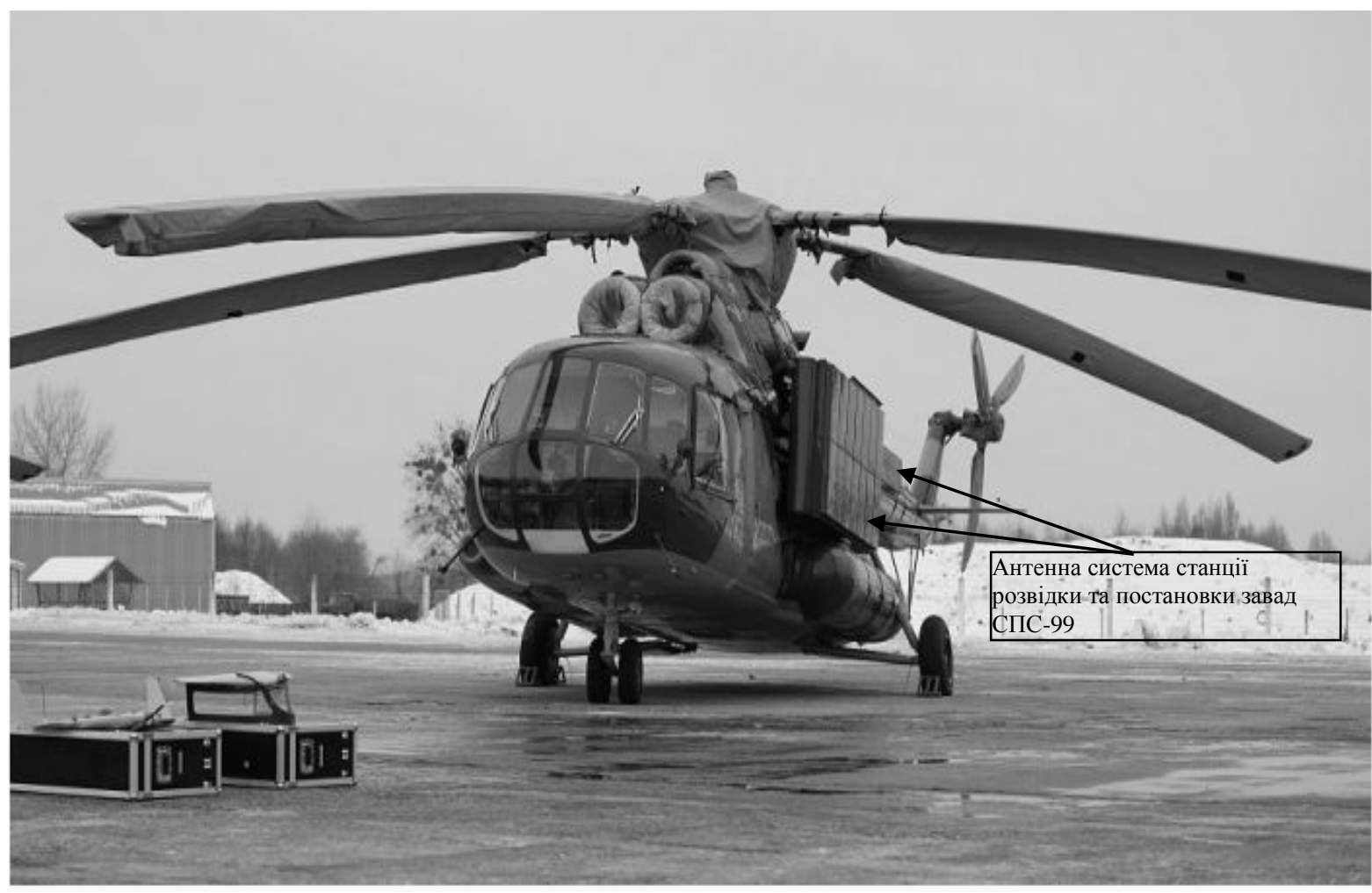

Рис. 2. Вертоліт Ми-8МТПИ (“Икебана”)

Крім того ці засоби можливо використовувати для ускладнення повітряної обстановки і закриттю окремих секторів і ділянок від сканування РЛС противника та подавлення радіоліній управління авіації. 
Спеціальне обладнання вертольоту має можливість виявляти сигнали також від систем літака дальнього радіолокаційного виявлення (ДРЛВ) та створювати завади роботи радіолокаційній станції (РЛС) цього літака із зон баражування над своєю територією. Це зменшує часові витрати на ідентифікацію об'єктів розвідки в інтересах органів управління. Такий підхід заснований на технології аналізу та синтезу, який має два рівня бортової обробки сигналу: визначення напрямку випромінювання і характер сигналу. В подальшому це впливає на формування загороджувальних шумових завад або завад з лінійночастотною модуляцією. Але ж ця робота пов'язана 3 справністю блоків гетеродинів в якому закладений алгоритм максимального збереження ключової інформації до формування загороджувальних шумових завад [10-12]. собою.

Мета статті. Існуючий дисбаланс щодо достовірності отримання даних радіорозвідки, який пов'язаний $з$ проблематичністю забезпечення справності складових частин спеціального бортового радіоелектронного обладнання вертольота, через брак технології військового ремонту, спонукає до створення методології відновлення такого обладнання. Це забезпечить зменшення працевтрат на усунення несправності та збільшення коефіцієнту безвідмовної роботи такого обладнання в цілому.

Мета статті полягає в розробці методу перевірки та військового ремонту блоку гетеродинів (Л16123) шляхом створення моделі пошуку несправностей блоку гетеродинів, що забезпечує зменшення працевтрат на усунення несправності та збільшення коефіцієнту безвідмовної роботи станції в цілому.

Довідка: блок Л161-23 має чотири гетеродина, які приймають участь в приймальному та передавальному трактах парних каналів надвисокої частоти у визначеному діапазоні F. Вище згадані гетеродини задають такт роботи другої ступені відтворення частоти та логічної обробки вхідних сигналів станції СПС-99.завад [10-12].

\section{Виклад основного матеріалу}

Бортова станція СПС-99, під час радіорозвідки, має дві ступені визначення високої частоти. Перша ступінь системи визначення високої частоти, що входить до складу бортової станції СПС-99 має вісім частотних каналів що визначає несучу частоту 3 дискретністю 66 МГц. До складу першої ступені цієї системи входить два блоки гетеродинів Л161-23.

Завдання роботи цих блоків - генерування восьми напруг фіксованої частоти. Всього таких гетеродинних напруг визначеної частоти вісім. Один блок гетеродинів генерує напруги гетеродинів, які мають парне числення. Другий блок генерує напруги гетеродинів з непарним численням.

Завдяки цьому вхідні сигнали радіолокаційних станцій, що підлягають розвідці, переносяться до єдиного загального діапазону проміжних частот другої ступені системи визначення високої частоти.

В подальшому вступають в дію порогові пристрої, фільтрація, кодування та визначення даних розвідки.

Основними складовими блоку гетеродинів $є$ модуль ГТВ 4, який складається з таких приладів:

- A1-пристрій регулювання температури $\mathrm{t}^{\circ} \mathrm{C}$;

- A2, A3, А5, А6 - автогенератори 3 фазовим автоматичним налаштуванням частоти. Вони позначені, як прилади С4;

- A4 - кварцовий генератор опорної частоти, прилад ГК-12.

Загальний вид гетеродинного блоку Л161-23 наведений на рис. 3. Отримані зображення після виконання демонтажних робіт надані на рис. 4 .

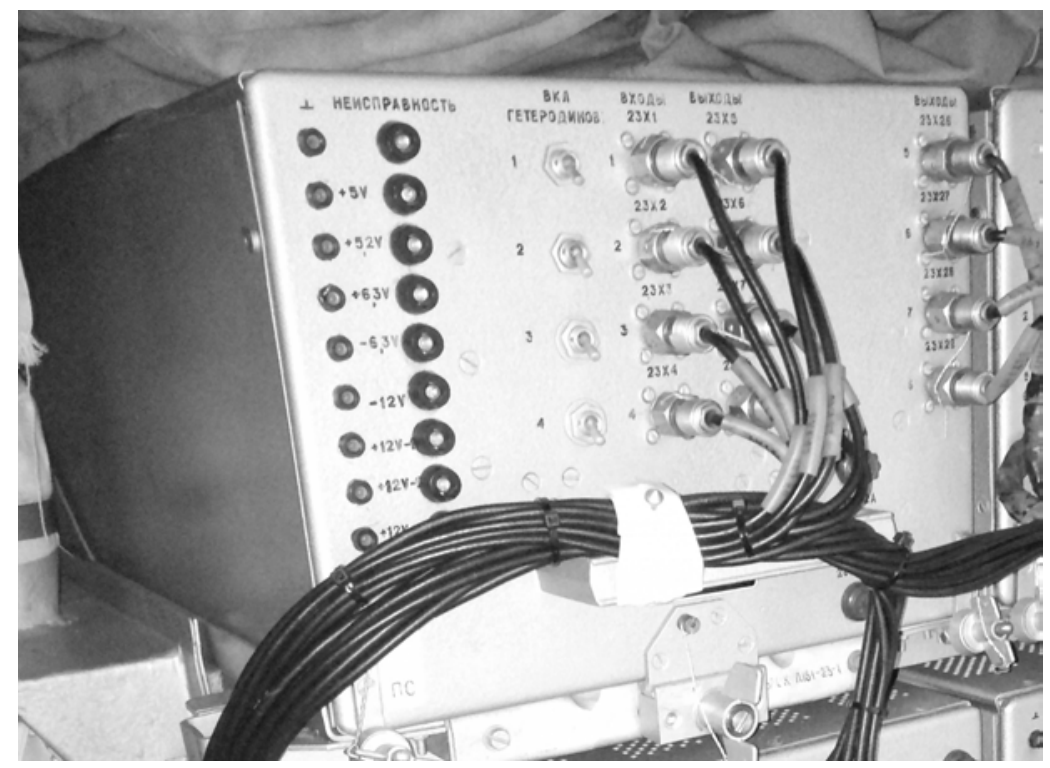

Рис. 3. Гетеродинний блок Л161-23 зовні 


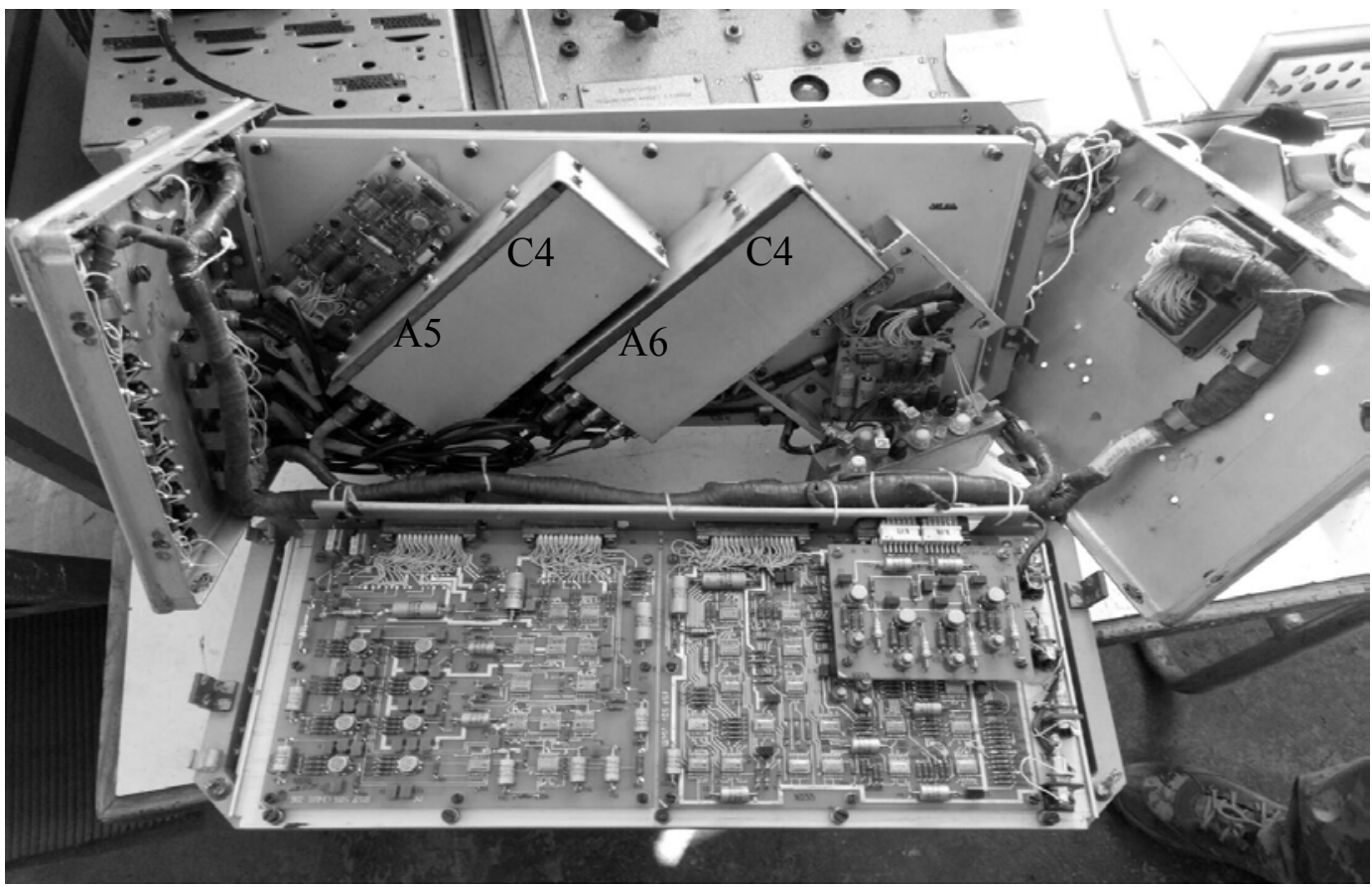

Рис. 4. Гетеродинний блок Л161-23 всередині

Функціональна схема приладу С4 модулю ГТВ 4 гетеродинного блоку Л161-23 наведена на рис. 5.

Довідково: модуль ГТВ 4 в своєму складі має чотири автогенератори 3 фазовим автоматичним налаштуванням частоти (прилад С4). В блоці Л16123-1 вини позначені як А2, A3, А5, А6 і генерують гетеродинні напруги $\left(f_{\text {гn }}\right)$ для парних каналів. В блоці Л161-23-2 присутні аналогічні автогенератори 3 фазовим автоматичним налаштуванням частоти (прилад C4), але генерують гетеродинні напруги $\left(f_{\text {гn }}\right)$ для непарних каналів.

Робота гетеродинного блоку полягає в наступному. Генератор опорної частоти (прилад ГК-12) видає напругу опорної частоти $f_{\text {on }}=206,25 \kappa Г$, яка надходить до входу Х3 автогенератори 3 фазовим автоматичним налаштуванням частоти, тобто приладу C4. Ця напруга, з визначеною частотою, призначена для кварцової стабілізації частот автогенераторів 3 літерами A2, A3, A5, А6 (прилади С4). Кожен автогенератор $\mathrm{C} 4$ повинен видавати напругу фіксованої частоти $\left(f_{21}, \mathrm{MГц;} f_{23}, \mathrm{MГц;} f_{25}, \mathrm{MГц;}\right.$ $f_{27}, \mathrm{M \Gamma ц)}$

Було з'ясовано, що прилад С4 має герметичний та екранований корпус в якому розміщені такі електронні плати:

- An1 - генератор що управляється напругою (ГУН);

- An2 - фазовий детектор (ФД);

- An3 - дільник з постійним коефіцієнтом ділення (ДПКД);

- An4 - дільник із змінним коефіцієнтом ділення (ДЗКД).
Експериментально було з'ясовано, що на контакті $23 \mathrm{X} 7$ відсутне номінальне значення частоти гетеродину $f_{25}$, МГц, а на контакті $23 \mathrm{X} 8$ номінальне значення частоти гетеродину $f_{27}$, МГц не стабільне (іноді має значно занижені значення параметру) .

В подальшому було здійснено дослідження приладу C4, а саме літерний автогенератор 3 фазовим автоматичним налаштуванням частоти А5 Тобто третій гетеродин ( $f_{25}$, МГц).

Експериментально було визначено, що автогенератори 3 фазовим автоматичним налаштуванням частоти, тобто прилад $\mathrm{C} 4$, має вісім електричних виводів Z1 ...Z8 з певними значеннями напруг:

1) $\mathrm{Z} 1-+5 \mathrm{~B}$;

2) $\mathrm{Z} 2-+5,3 \mathrm{~B}$;

3) $\mathrm{Z3}-+6,3 \mathrm{~B}$;

4) $\mathrm{Z} 4-+12 \mathrm{~B}$;

5) $\mathrm{Z5}$ - мінус 12B;

6) $\mathrm{Z} 6-+27 \mathrm{~B}$;

7) $\mathrm{Z7}-+27 \mathrm{~B}$

8) Z8 - заземлення;

9) Х1 - ВЧ вихід $1\left(f_{2 n}\right)$;

10) Х2 - ВЧ вихід $2\left(f_{2 n}\right)$;

11) X3 - вхід 3 кварцового генератора опорної частоти $\left(f_{\text {on }}\right)$.

3 метою стабілізації частоти гетеродину на вивід $Z_{7}$ надходить напруга +27 д для підігріву мікросхеми. 


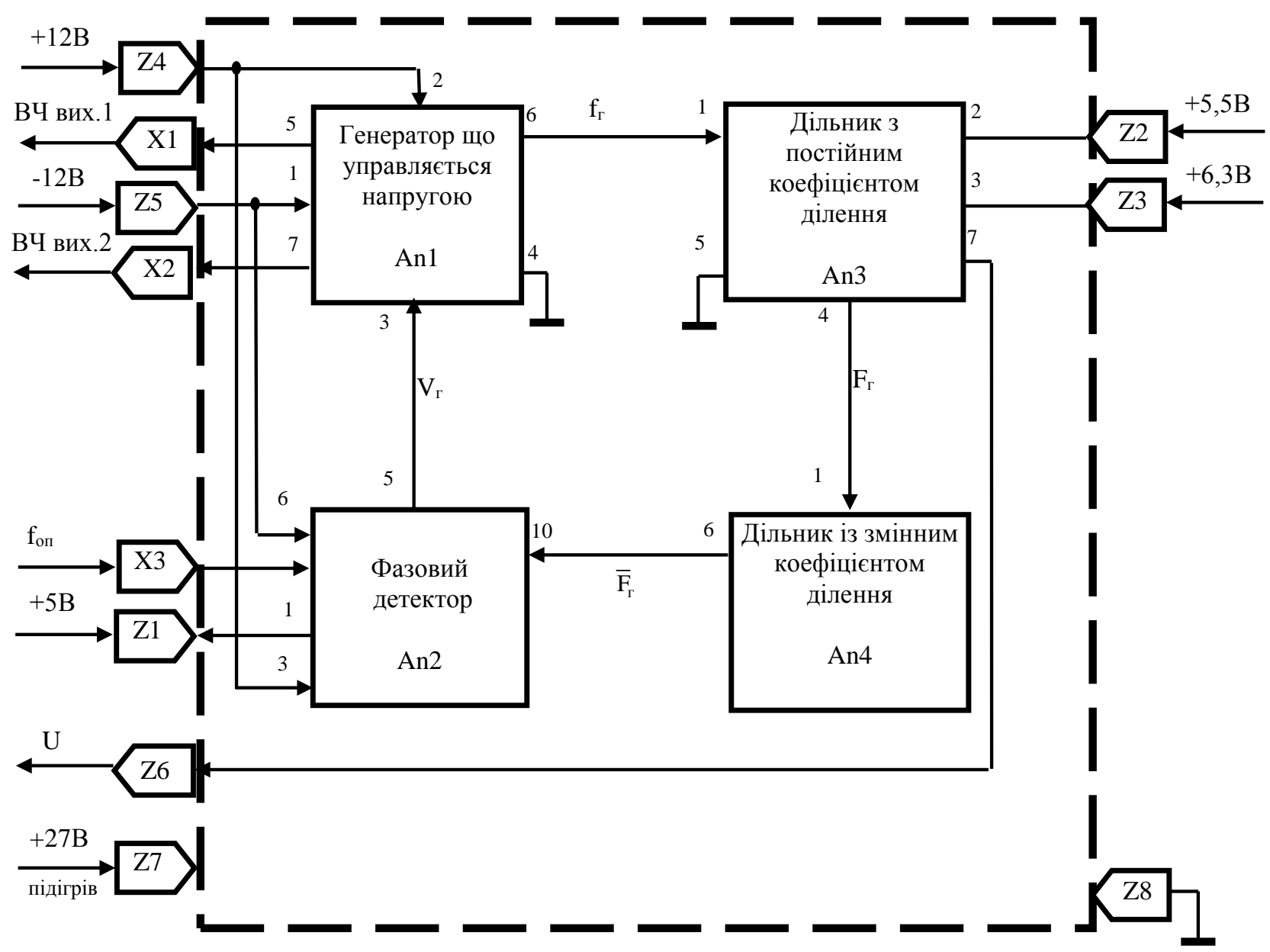

Рис. 5. Функціональна схема автогенератора з фазовим автоматичним налаштуванням частоти (прилад С4) модулю ГТВ 4 гетеродинного блоку Л161-23

Джерело: відпрацьовано самостійно.

Дільник 3 постійним коефіціснтом ділення (прилад An3) видає напругу частотою $F_{2}$ :

$$
F_{2}=\frac{f_{2}}{K_{A 3}},
$$

де $f_{2}$ - напруга частотою що надходить з ГУН;

$K_{A 3}$ - постійний коефіцієнт ділення приладу An3.

Дільник із змінним коефіцієнтом ділення (прилад $\mathrm{An} 4)$ видає напругу частотою $\bar{F}_{2}$ :

$$
\bar{F}_{2}=\frac{f_{2}}{K_{A 3} K_{A 4}},
$$

де $K_{A 4}$ - змінний коефіцієнт ділення приладу An4.

В свою чергу 3 фазового детектора (прилад An2) надходить керуюча напруга $V_{2}$ до генератора, що управляється напругою (прилад An1).

Довідка: виміри виконувались частотоміром на контактах 23X5, 23X6, 23X7, 23 X8.
Зовнішній вид приладу С4 гетеродинного блоку Л161-23 наведений на рис.6 (сторона А) та рис. 7 (сторона В).

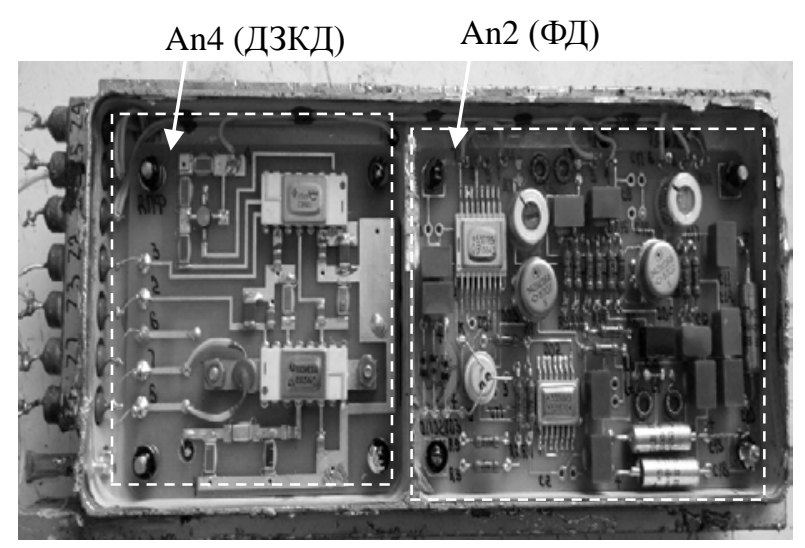

Рис. 6. Загальний вид автогенератора з фазовим автоматичним налаштуванням частоти (прилад C 4) гетеродинного блоку (сторона А) 
В подальшому було досліджено генератор що управляється напругою ГУН-33 (плата А1) приладу C 4.

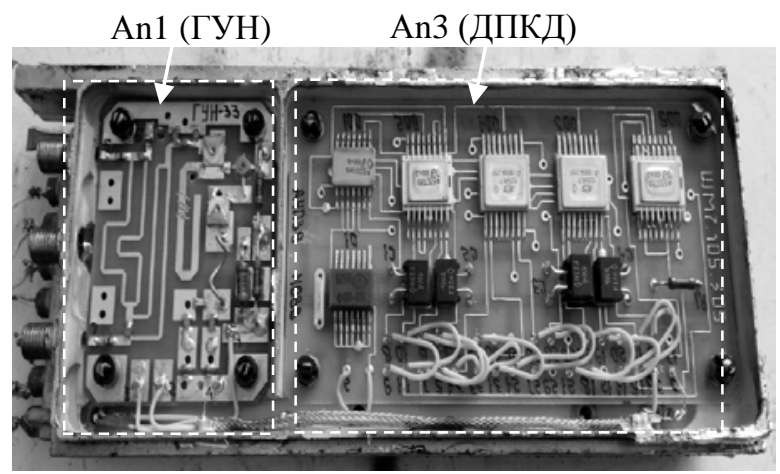

Рис. 7. Загальний вид автогенератора з фазовим автоматичним налаштуванням частоти (прилад C4) гетеродинного блоку (сторона Б)

ГУН-33 п’ятого гетеродину $\epsilon$ автогенератор який повинен видавати напругу частотою гетеродину fг5, МГц (виходи X1 та Х2). Живлення гетеродину здійснюється по колу плюс $12 \mathrm{~B}$ та мінус $12 \mathrm{~B}$. Електричний зв'язок мінус 12В здійснюється по колу Z5 - контакт 1 плати An1(ГУН) - контакт 6 плати An2 (ФД) .

При наявності напруги плюс 12В та мінус 12В на вказаних контактах, на X1 спостерігається наявність напруги номінальної частоти $f_{25}$, МГц. Але ж одразу напруга мінус 12B падає до значення мінус 4,5B та частота на X1 зменшується майже в три рази, або зовсім зникає. Це і $є$ прояв відмови роботи гетеродину. Аналогічна ситуація відбувається із сьомим гетеродином: $f_{27}$, МГц при напрузі мінус 12B; при мінус 4,5B значення частоти гетеродину також зменшується у два-три рази.

Виходячи 3 цього, можна зробити висновок, що робоча точка гетеродину має зміщення від номінальної, а отже варікап автогенератора отримує не робочу напругу. Коректність цього твердження обумовлена тим, що значення частоти гетеродину отримано експериментальним шляхом та після корекції схемних елементів це значення отримало номінальне вихідне значення.

\section{Висновки}

Розроблений метод перевірки та військового ремонту блоку гетеродинів Л161-23 зі складу станції СПС-99, з метою усунення зміщення робочої точки гетеродину від номінальної, передбачає суттєво підвищити достовірність отриманих даних радіорозвідки а також вплинути на оперативність постановки потрібної завади. Це дозволяє:

- підвищити надійність роботи автогенератора 3 фазовим автоматичним налаштуванням частоти (C4) гетеродинного блоку;

- усунути похибки визначення даних радіорозвідки зокрема несучої частоти, яка залежить взагалі від нестабільності частот налаштування і ширини полоси пропускання фільтрів другої ступені системи визначення високої частоти;

- зменшити часові витрати на ідентифікацію об'єктів розвідки;

- підвищити оперативність та точність постановки завади у визначеному діапазоні та напрямку;

- корегувати роботу станції, з боку оператора, шляхом відтворення набору безперервних гармонійних сигналів, при постановки завади за визначеною шириною спектра загороджувальної завади, або спектру прицільної завади.

Інноваційний підхід виконання робіт на вертольоті Ми-8МТПИ дозволило підвищити ефективність його застосування під час проведення постановки завади з положення на землі, а також із зони баражування в повітрі.

\section{Список літератури}

1. Никольский Б.А. Основы радиоэлектронной борьбы / Б.А. Никольский. - Самара: Изд. Самарского университета, 2018. - 268 с.

2. Семенихина Д.В. Теоретические основы радиоэлектронной борьбы. Радиоэлектронная разведка и радиоэлектронное противодействие / Д.В. Семенихина, Ю.В. Юханов, Т.Ю. Привалова. - Таганрог: Изд. ЮФУ, 2015. - $252 \mathrm{c}$.

3. Кожушко Я.Н. Тенденції розвитку авіаційних засобів радіоелектронної боротьби військово-повітряних сил США / Я.Н. Кожушко // Наука и техніка Повітряних сил Збройних Сил України. - 2011. - № 2(6). - С. 44-48.

4. Сонин А.П. Облик перспективной авиационной бортовой станции активных помех / А.П. Сонин // Цифровые радиоэлектронные системы. - 2004. - № 5. - С. 32-36.

5. Добыкин В.Д. Радиоэлектронная борьба. Цифровое запоминание и воспроизведение радиосигналов и электромагнитных волн / В.Д. Добыкин, А.И. Куприянов, В.Г. Пономарев. - М.: Вузовская книга, 2009. - 360 с.

6. Перунов Ю.Н. Радиоэлектронная борьба: радиотехническая разведка / Ю.Н. Перунов, А.И. Куприянов. - М.: Изд. Вузовская книга, 2016. - 190 с.

7. The ensuring the integrity of information streams under the cyberattacks action / V. Barannik, S. Podlesny, A. Krasnorutskyi, A. Musienko, V. Himenko // 2016 IEEE East-West Design \& Test Symposium (EWDTS). - Yerevan. - pp. 1-5.

8. Lu G. Cancellation of Complicated DRFM Range False Targets via Temporal Pulse Diversity / G. Lu // Progress In Electromagnetics Research C. - 2010. - Vol. 16. - P. 69-84. 
9. Model intelligent processing of aerial photographs with a dedicated key features interpretation / V. Barannik, A. Krasnorutskiy, Y. Ryabukha, D. Okladnoy // Modern Problems of Radio Engineering, Telecommunications and Computer Science. - 2016. - P. 736. https://doi.org/10.1109/TCSET.2016.7452167.

10. Barannik V.V. Methodological base for transformants representation in nonequilibrium positional uneven-diagonal space / V.V. Barannik, A.A. Krasnorutskyi, A.P. Musienko // Science-Based Technologies. - № 3(27). - 2015. - pp. $233-238$.

11. Model of syntactic representation of aerofhoto images segmantes / V. Barannik, A. Krasnorutskiy, A. Hahanova, S. Shulgin // IEEE 14th International Conference "Advanced trends in radioelectronics, telecommunications and computer engineering (TCSET)”, (Lviv-Slavske, Ukraine, February 20 - 24, 2018). - Lviv Polytechnic National University, 2018. P. 281-284.

12. Barannik V. The positional structural-weight coding of the binary view of transformants / V. Barannik, A. Krasnorutskiy, A. Hahanova // East-West Design \& Test Symposium, 2013. - P. 1-4.

\section{References}

1. Nicolskiy, B.A. (2018), "Osnovy radioelektronnoj bor'by" [The basics of electronic warfare], Izd. Samarskogo universiteta, Samara, $268 \mathrm{p}$.

2. Semenikhina, D.V., Yuhanov, Yu.V. and Privalova, T.Yu. (2015), “Teoreticheskie osnovy radioelektronnoj bor'by. Radioelektronnaya razvedka i radioelektronnoe protivodejstvie" [Theoretical foundations of electronic warfare. Electronic intelligence and electronic countermeasures], Izd. YuFU, Taganrog, $252 \mathrm{p}$.

3. Kozhushko, J.N. (2011), "Tendenciyi rozvitku aviacijnih zasobiv radioelektronnoyi borot'bo vijs'kovo-povitryanih sil SSHA" [Trends in the development of aviation means of electronic combat US Air Force], Science and Technology of the Air Force of Ukraine, No. 2(6), pp. 44-48.

4. Sonin, A.P. (2004) “Oblik perspektivnoj aviacionnoj bortovoj stancii aktivnyh pomekh” [The appearance of a promising aircraft side station active interference], Digital electronic systems, No. 5, pp. 32-36.

5. Dobykin, V.D., Kupriyanov, A.I. and Ponomarev, V.G. (2009), "Radioelektronnaya bor'ba. Cifrovoe zapominanie $i$ vosproizvedenie radiosignalov i elektromagnitnyh voln" [Electronic warfare. Digital storing and reproduction of radio signals and electromagnetic waves], Vuzovskaya kniga, Moscow, 360 p.

6. Perunov, Y.N. and Kupriyanov, A.I. (2016), “Radioelektronnaya bor'ba: radiotekhnicheskaya razvedka” [Electronic warfare: electronic intelligence], Vuzovskaya kniga, Moscow, 190 p.

7. Barannik, V., Podlesny, S., Krasnorutskyi, A., Musienko, A. and Himenko, V. (2016), The ensuring the integrity of information streams under the cyberattacks action, 2016 IEEE East-West Design \& Test Symposium (EWDTS), Yerevan, pp.1-5.

8. Lu, G. (2010), Cancellation of Complicated DRFM Range False Targets via Temporal Pulse Diversity, Progress In Electromagnetics Research, Vol. 16, pp. 69-84.

9. Barannik, V., Krasnorutskiy, A., Ryabukha, Y. and Okladnoy, D. (2016), Model intelligent processing of aerial photographs with a dedicated key features interpretation, Modern Problems of Radio Engineering, Telecommunications and Computer Science, pp. 736. https://doi.org/10.1109/TCSET.2016.7452167.

10. Barannik, V.V., Krasnorutskyi, A.A. and Musienko, A.P. (2015), Methodological base for transformants representation in nonequilibrium positional uneven-diagonal space, Science-Based Technologies, No. 3(27), pp. 233-238.

11. Barannik, V., Krasnorutskiy, A., Hahanova, A. and Shulgin, S. (2018), Model of syntactic representation of aerofhoto images segmantes, IEEE 14th International Conference, "Advanced trends in radioelectronics, telecommunications and computer engineering (TCSET)”, Lviv Polytechnic National University, Lviv, Ukraine, pp. 281-284.

12. Barannik, V., Krasnorutskiy, A. and Hahanova, A. (2013), The positional structural-weight coding of the binary view of transformants, East-West Design \& Test Symposium, pp.1-4.

Надійшла до редколегії 28.02.2020

Схвалена до друку 10.03.2020

\section{Відомості про авторів:}

\section{Шмаков Віталій Валерійович}

кандидат технічних наук

начальник кафедри

Харківського національного

університету Повітряних Сил ім. І. Кожедуба,

Харків, Україна

https://orcid.org/0000-0003-3668-7281

\section{Бараннік Володимир Вікторович}

доктор технічних наук професор

начальник кафедри Харківського національного

університету Повітряних Сил ім. І. Кожедуба,

Харків, Україна

https://orcid.org/0000-0002-2848-4524

\section{Information about the authors:}

\author{
Vitalii Shmakov \\ Candidate of Technical Science \\ Head of Department \\ of Ivan Kozhedub Kharkiv \\ National Air Force University, \\ Kharkiv, Ukraine \\ https://orcid.org/0000-0003-3668-7281
}

\author{
Vladimir Barannik \\ Doctor of Technical Science Professor \\ Head of Department of Ivan Kozhedub Kharkiv \\ National Air Force University, \\ Kharkiv, Ukraine \\ https://orcid.org/0000-0002-2848-4524
}


Красноруцький Андрій Олександрович

кандидат технічних наук

викладач

Харківського національного університету

Повітряних Сил ім. І. Кожедуба,

Харків, Україна

https://orcid.org/0000-0001-9098-360X

Федоровський Олександр Володимирович

викладач

Харківського національного університету

Повітряних Сил ім. І. Кожедуба,

Харків, Україна

https://orcid.org/0000-0001-5016-8926

Олексін Олександр Олександрович

викладач

Харківського національного університету

Повітряних Сил ім. І. Кожедуба,

Харків, Україна

https://orcid.org/0000-0002-6666-3187

\author{
Andrii Krasnorutsky \\ Candidate of Technical Science \\ Instructor \\ of Ivan Kozhedub Kharkiv \\ National Air Force University, \\ Kharkiv, Ukraine \\ https://orcid.org/0000-0001-9098-360X \\ Oleksander Fedorovskiy \\ Instructor \\ of Ivan Kozhedub Kharkiv \\ National Air Force University, \\ Kharkiv, Ukraine \\ https://orcid.org/0000-0001-5016-8926 \\ Oleksandr Oleksin \\ Instructor \\ of Ivan Kozhedub Kharkiv \\ National Air Force University, \\ Kharkiv, Ukraine \\ https://orcid.org/0000-0002-6666-3187
}

\title{
МЕТОДИКА ПРОВЕРКИ И ВОЙСКОВОГО РЕМОНТА БЛОКА ГЕТЕРОДИНОВ СТАНЦИИ РЭБ СПС-99 ВЕРТОЛЕТА МИ-8МТПИ (“ИКЕБАНА”)
}

В.В. Шмаков, В.В. Баранник, А.А. Красноруцкий, А.В. Федоровский, А.А. Олексин

Раскрыта методология радиотехнической разведки и постановки помех из наземного положения и зон барражирования вертолета. Предлагается метод войскового ремонта блока гетеродинов станции СПС-99, который обеспечит уменьшение трудозатрат на устранение неисправности и увеличение коэффициента ее безотказной работы. Предлагается модель измерения и корректировки поточных параметров номиналов в блоке гетеродинов. Направление исследований: уменьшение временных затрат на поиск и устранение неисправности путем моделирования работы функииональной схемы автогенератора с фазовой автоподстройкой частоты гетеродинного блока.

Ключевые слова: радиоэлектронная борьба, радиоразведка, гетеродин, автогенератор, частота.

\section{METHOD OF INSPECTION AND MILITARY REPAIR OF THE HETERODINES BLOCK OF THE EW SPS-99 STATION OF THE MI-8MTPI HELICOPTER (“IKEBANA")}

\author{
V. Shmakov, V. Barannik, A. Krasnorutsky, O. Fedorovskiy, O. Oleksin
}

The article outlines an innovative approach to performing work on a Mi-8MTPI helicopter in order to increase its efficiency. The direction of restoration of the aviation electronic warfare system in Ukraine is determined. The methodology of radio reconnaissance and setting sighting in frequency and direction of interference, as well as barrage interference from the ground position and from the helicopter's barrage zone is disclosed. The stages of converting received radio intelligence data by the SPS-99 station and determining the direction and shape of the signal by frequency conversion are justified. A method for checking and repairing a unit of oscillators L161-23 from the SPS-99 station is proposed. The scientific and applied field of research : reducing the time spent on troubleshooting by introducing the developed heterodyne block circuit taking into account structural and combinatorial features of the placement of the element base and ways to maintain the operability of such elements in the future are identified. A model for troubleshooting the local oscillator block, which provides a reduction in labor costs for troubleshooting and an increase in the plant's failure-free operation coefficient is proposed. A detailed description of troubleshooting, measuring current parameters and adjusting the nominal values of the parameters generated by the oscillator with phase automatic frequency control of the local oscillator block is provided. The model of a functional diagram of a selfoscillator with a phase automatic frequency control is proposed. The developed method allows to increase the reliability of the oscillator with phase automatic tuning of the frequency of the heterodyne block; eliminate errors in the determination of radio intelligence data, in particular, the carrier frequency, which depends on the instability of the tuning frequencies and the bandwidth of the filters of the second degree of the high frequency detection system; reduce time spent on the identification of reconnaissance objects; increase the efficiency and accuracy of jamming in a certain range and direction; to correct the station's work from the operator's side by reproducing a set of continuous harmonic signals when interfering with a certain width of the spectrum of the obstacle interference. The research results can be used to modernize existing models and develop advanced electronic warfare systems

Keywords: electronic warfare, radioreconnaissance, oscillator, autogenerator, frequency. 